Асыл М.Б.

Орталық Азиядағы Қытай факторы

Assyl M.B.

\section{Chinese factor in Central Asia}

Асыл М.Б.

Китайский фактор в Центральной Азии
Бұл мақалада Қытайдың Орталық Азияда жүргізіп отырған саясатын қарастыру арқылы Қытай Халық Республикасы мен Қазақстан арасындағы қырам-қатынасқа сараптама беріледі. Геосаяси жағдайларға баға беріліп, екі ел арасындағы шекара және экономикалық мәселелер де қарастырылады. Сонымен қатар ҚХР-ға қатысты этникалық мәселелер де қозғалып өтіледі.

Түйін сөздер: ҚХР, Қазақстан, геосаясат, ШЫҰ, экономика, қарым-қатынас.

In this paper the author investigate the Chinese factor in Central Asian countries. Through the prism of the geopolitical situation in Central Asia, the author evaluates the relationship of China and the RK. The author also reviewed the internal problems of China that may have an impact on China's policy in Central Asia.

Key words: CPR, Kazakhstan, geopolicy, SCO, economy, relationship.

В Аанной статье автор рассматривает китайский фактор в странах Центральной Азии. Через призму геополитической ситуации в ЦА автор дает оценку взаимоотношениям КНР и РК. Также автор исследует внутренние проблемы Китая, которые могут оказать влияние на политику Китая в ЦА.

Ключевые слова: КНР, Казахстан, геополитика, ШОС, экономика, взаимоотношения. 


\section{ОРТААЫҚ АЗИЯААҒЫ ҚЫТАЙ ФАКТОРЫ}

Қазіргі Қытай Халық Республикасы қарқынды дамып келе жатқан мемлекет, күшті саяси орталық. Бүгінде ол әлемдік экномиканың даму тізімінде АҚШ пен Жапониядан кейінгі үшінші орында болса, сыртқы сауда көлемі бойынша төртінші орынды иеленген. ХХІ ғасырдың ортасына қарай ҚХР алдыңғы қатарлы әлемдік держава болатынын түсіне отырып, онымен ынтымақтастықты дамытуға мүдделі мемлекеттер саны да барған сайын артуда. Қазіргі саясатта Қытайдың көзқарасымен санаспай халықаралық қатынастардың ешбір ойыншысы әрекет ете алмайды. Біріншіден, Қытай БҰҰ-ның Қауіпсіздік Кеңесінің тұрақты мүшесі. Екіншіден, ҚХР аумақ, халық, табиғи ресурстар, индустриалдық және ғылыми база, ядролық қару, әлемдік мұхит пен ғарышқа ғаламдық дәрежеде қатысу сияқты маңызды факторларға ие. Үшіншіден, Қытай өз мүдделерін қорғауда принципті түрде халықаралық ынтымақтастыққа, халықаралық құқыққа және БҰҰ-ның беделіне сүйенеді. ҚХР үшін айнымас қағида ретінде халықаралық мәселелер мен қайшылықтарды шешуде күштеу және біржақты қабылданатын әдістерді қолданбау қала бермек. 2015 жылы Казақстан Республикасының Президенті Н.Ә. Назарбаев мемлекеттің сыртқы саясатының басымды бағыттарын анықтай келе, ҚХР-мен қатынасты бірінші орынға қойғаны белгілі. Осы орайда ҚХР Орталық Азия мемлекеттері арасындағы тарихи қатынастарды сараптау мен бүгінгі геосаясатты анықтаудың маңызы зор болып отыр [1]. 1996 жылы сәуірде Шанхайда ҚХР, РФ, ҚР, Қырғызстан Республикасы және Тәжікстан арасында КСРО-ның бұрынғы республикалары мен Қытайдың арасындағы көпжылдық өзара түсініспеушілік пен сенімсіздіктің негізіне нүкте қойылды. Шанхай кездесуі, сол кездегі, КСРО-дан қалған территориялық, шекаралық мәселелерді шешті. Қазақстандық сарапшылардың пікірінше, Қытайдың Қазақстандағы және Орталық Азиядағы саясатына өткен тарихтың әсері әлі де сезілуде. Бұл жағдайды ҚХР қазіргі қалыптасып отырған жаңа геосаясатта да пайдаланып отыр [2].

Қырғи-қабақ соғыс кезіндегі қалыптасқан жағдайды, Қытайдың ішкі және сыртқы саясатын сараптай келе, белгілі геосаясатшы М. Лаумулин былай деп атап көрсетеді: «Шығыс Түркістандағы Қытай саясаты туралы алғашқы ірі ғылыми ең- 
бекті жазған Р. Проис пен Г. Лиас. Олардың еңбектерінде Шығыс Түркістандағы ұлт-азаттық қозғалысты талқандаушы және қазақ ауылдарының Үндістан мен Пәкістанға көшуі баяндалған. Сол сияқты Дж. Дрейер және С.Э. Уимбуш еңбектерінде Шыңжандағы мұсылмандардың ассимиляциясы және бейімделуі үрдістері сарапталған. Бұл авторлар Қытай үкіметінің мәдени саясатына және аз ұлттарға репрессиясы, Шыңжаң, кеңесқытай қатынастарына да назар аударады.

Автордың пікірінше, XX ғасырдың 70-80 жж. жарық көрген еңбектерде негізінен КСРОҚытай қатынастарындағы Шыңжан факторы басым болған [3]. Ал, И.Сванберг және И.Бенсон еңбектерінде 1930-1950 жылдардағы Шығыс Түркістандағы, 1944-1949 жылдардағы Іле аймағындағы Осман батыр бастаған қазақтардын көтерілісі және оның жасақтарының Оңтүстік Азия мен Түркияға шегінуі баяндалған. Жалпы Батыс зерттеушілерінің бұл жылдардағы еңбектеріндегі негізгі концепциясы, Қытай коммунисттерінің Шыңжанда жүргізген модернизация үрдістері, КСРО-ның Орта Азиядағы саясатына қарағанда өзгеше болды. Шыңжанда дәстүрлі исламды насихаттау, хандық Кытайдың ассимиляция үрдісіне қарсы күрес тамырын терең жайып, дәстүрлі қоғам өз сипатын сақтап қалды. Ал, КСРО-ның саясатының нәтижесінде Орта Азиядағы орыстандыру (кеңестендіру) үрдісінің қаншалықты болғаны белгілі. Дегенмен де КСРО ыдырағанға дейін Қытайдың ресми саясатына түркі-мұсылмандық халықтардың қарсылығын болжап, баға беруге арналған еңбектер саны аз. Орта Азияда жаңа тәуелсіз мемлекеттердің пайда болуы аймақтағы геосаяси жағдайды өзгертті [4] . Күн тәртібінде Орталық Азияға Қытай тарапынан келетін қауіп, түрік сепаратизмі, Орталық Азия мемлекеттерінің Ресеймен, Қытаймен байланысы, ҚХР мен Орталық Азия арасындағы демографиялық, экономикалық факторлар зерделеніп, өзектілігі артты. Америкалық зерттеуші Т.Фуллердің пікірінше, өзгерген геосаяси жағдайда ҚХР үшін Орталық Азия мемлекеттерімен қатынастарының маңыздылығы артады. Мәселен, Қытай Қазақстанға байланысты ұстамды саясат жүргізіп отыр. Оның басты себебі ұйғыр сепаратизмі. Қытай өзінің сыртқы саясатында этникалық мәселеге көп көңіл бөліп, бұл факторды Қытай-Ресей, Қазақстан-Қытай, Қазақстан-Ресей қатынастарының негізгі факторы ретінде қарастырады деп есептейді [5]. Ресми Пекин, егер ҚХР - Ресей арасындағы қатынастар қарқынды дами берсе, Қазақстаннан да ұстамды этникалық саясат жүргізуді талап етуге болады деп есептейді. Сонымен бірге, ҚХР посткеңестіктегі орны оның көрші мемлекеттермен шекара мәселесін реттеумен анықталды. Мысал ретінде Қазақстан мен Қытай арасындағы шекараны анықтау мәселесіне тоқталып өтейік. Бұл үрдіс 1992 жылы басталып, 1998 жылы аяқталды. Шекара мәселесі 1992 жылы ҚР премьер-министрі С. Терещенконың Қытайға сапары кезінде, 1994 жылы ҚХР Мемлекеттік Кеңесінің төрағасы Ли Пэнның Орталық Азия мемлекеттеріне сапары барысында, 1996 жылы Цзян Цзяминнің, 1997 жылы Ли Пэннің Алматыға сапарлары кезінде, сол сияқты Н.Ә. Назарбаевтың 1997 жылы ақпандағы және ҚР экс-премер министрі болған Н. Балғымбаевтың 1997 жылы мамыр айындағы Қытайға сапарларында, сондай-ақ Цзян Цзяминнің 1997 жылы қыркүйектегі Алматы сапарларында талқылады. Осы кездесулердің нәтижесінде 1997 жылы 29 қыркүйекте «Қазақстан-Қытай» арасындағы шекара мәселесіне байланысты қосымша келісімге қол қойылды. Қосымша келісім бойынша Чогон обо және Баймұрза аймағында Қазақстан саур қыратының оңтүстік бөлігі Чоган-оба өтпеліне дейін, Жүрек және Чогон-оба, Керегенты өзендерінің бір бөлігі (жалпы ұзындағы 442 кв.км.), Қытай - Адырбай және Талдыойрық өзендерінің жоғары ағысы, Баймырза өтпелінің Тарбағатай қыратының оңтүстік бөлігі (ұзындығы 187 кв.км.), Сарышелді аймағында Қазақстанға 95 кв.км. жер Сарышелді өзенінің сол жақ бөлігі, Шопақ өтпеліне дейінгі жер, Қытайға-Сарышелді өзенінің оң жақ бөлігі, жалпы ұзындығы 220 кв.км. өтті [6]. Бүгінгі таңда Қытай мен Қазақстан арасындағы шешімін таппай отырған мәселе «Қара Ертіс» трансшекаралар өзендері мәселесі. Бұл мәселе әлі де өз шешімін күтуде. 2013 жылғы Си Цзипиннің Астанаға сапары барысында, Қытай басшысы бұл мәселені өз бақылауына алатындығын баса айтқан болатын.

Сондай-ақ, Орталық Азиядағы жаңа геосаяси жағдайды анықтаудағы шешуші фактор ретінде, Қазақстан мен Қытайдың арасындағы экономикалық мәселелер деп тұжырым жасауға болады. Біздің ойымызша, Қытайдың Орталық Азиядағы және Қазақстандағы сауда-экономикалық қатынастарының қарқынды дамуы екі жақ үшін де тиімді болады. ҚХР бүгіннің өзінде жүргізілген реформалардың нәтижесінде әлемдік алпауыт мемлекетке айналып отыр. Өзінің ішкі өнімі бойынша жылдық өсімі 1980-1997 жж. 9\% болса, қазір бұл көрсеткіш үш еседей өсіп отыр. Егер де Қытайдың 30 провинциясын бір мемлекет деп алып қарастыратын болсақ, ал 
ондағы адам саны кейбір дамушы елдердегі адам санынан асып түседі, 1978-1995 жж. қарқынды дамып отырған 20 мемлекетке осы провинциялар ғана парапар. Сарапшылардың пікірінше, 2020 жылы Қытай ішкі өнім бойынша АҚШ-ты қуып жетеді деп жоспарлануда. КХР экономикалық өркендеуіне тағы мына мысал дәлел бола алады. 1995 жылы өнеркәсіптегі өндіріс құралдарының 90\%, 1980 жылдан кейін шығарылған, ірі және орта өнеркәсіп орындарындағы өндіріс құралдарының 26\%-ы дүние жүзінің алдыңғы қатарлы стандарттарға сәйкес келеді. 1997 жылы ҚХР сыртқы сауда көрсеткіші 325,1млр. долларды кұраса, бүгінде бұл сан екі есе өсіп отыр [7].

Қытайдың Орталық Азиядағы жаңа геосаяси орны туралы айтқан кезде, біз этникалық мәселені айналып өте алмаймыз. Мәселен, АҚШтың Миссурий университетінің профессоры Р. Дж. Кайзер Қытайдан Қазақстанға көшетін эмигранттардың легі, Қазақстандағы этно-демографиялық ахуалды өзгертеді деп есептесе, ал М. Олкоттың пікірінше Қазақстан үшін ұйғыр ұлтшыл күштерін қолдау Қазақстан-Қытай қатынастарына кері әсер етіп қана қоймай, ұйғыр ұлтшылдығының Қазақстанда таралуы да мүмкін деп есептейді [8].

Біздің пікірімізше, Қытай болашақта, Орталық Азия мен Қазақстанда өзінің экономикалық куаттылығын барынша кең пайдаланады. Бұл ҚХР-дың Орталық Азиядағы негізгі стратегиясы. ҚХР және Орталық Азия мемлекеттерінің арасындағы дипломатиялық, сауда-экономикалық, мәдени қатынастардың дамуына, тарихтан қалған кейбір күрделі мәселелердің шешілуіне қарамастан, бүгінде жалпы Орталық Азиядағы жағдайды өзгерте алатын мәселелер бар. Бұл ғаламдық және Қытайдың «ішкі» даму мәселелері. Орталық Азия мемлекеттері үшін, бұл өздерін егемен мемлекет құқында сақтап қалу және әлемдік өркениеттегі өз орнын алу болса, ҚХР үшін, ол 2015 ж. дейін алдыңғы қатарлы мемлекеттер қатарына қосылу, экономикасының өсу динамикасын төмендетіп алмау. Сондықтан да алдағы уақытта Қытай бірнеше қиындықтармен кездесуі мүмкін. ҚХР-дың даму қарқынына сараптама жасай келе қазақстандық зерттеуші К.Л. Сыроежкин негізгі қиындықтарды атап көрсетеді. Олардың қатарында:
1. Халық санының өсуі, қызмет атқаратын адамдардың санының азаюы, қарттардың санының көбеюі;

2. Ауыл шаруашылығының төмендеуі;

3. Қоршаған ортаны жақсарту мен экологиялық мәселе;

4. Тұтынатын заттарды қарқынды өндірудің қажеттілігі, астық өндірудің тиімділігі мен өнімділігі;

5. Ұлттық аймақтағы сепаратизм, Орталық пен ауылдар арасында қатынастардың шиеленісуі;

6. ҚХР жоғарғы билік басындағы саяси дағдарыстың шиеленісуі, фракциялық саяси дағдарыс;

7. Қалалық жердегі экономикадағы мемлекеттік сектордың дамуы мәселесі;

8. Экономикалық реформалардың әлеуметтік зардаптары, топтардың және ауылдық жерлердегі жұмыссыздықтың көбеюі;

9. Әлемдегі геосаяси жағдайдың тұрақсыздығы.

Оның ішінде Орталық Азия, Азия-Тынық мұхит аймағындағы жағдайға байланысты. Сол сияқты әлемдік қаржы дағдарысының салдары және т.б. [9].

Бұл факторлардың бәрі ҚХР мен Орталық Азия мемлекеттері арасындағы жағдайға тікелей әсер етеді. Өзінің демографиялық, табиғи географиялық және әлеуметтік-экономикалық ерекшеліктеріне сәйкес және дүние жүзілік геосаяси жағдайдың өзгеруі Қытай алдында үлкен мәселелерді қойып отыр. Алдағы уақытта Қытай негізінен екі мәселені шешуі қажет деп есептейді.

Біріншіден, ҚХР жалпы адамзат алдында тұрған ғаламдық мәселелерді шешуге атсалысуы мүмкін, немесе ол «шиеленіс» заманына қайта бой ұрып, Қытай идеологиясын, территориялық бақталастық геосаясатына оралуы мүмкін. Ол жағдайда «территориялық кеңейту» саясатын Қытай Қазақстаннан бастамайтынына кім кепілдік бере алады?

Қытайдың геосаяси кеңістіктегі алатын орны және ондағы реформалардың барысы туралы өз пікірін білдіре келе, ҚР Сенат мүшесі, ҚР-дың ҚХР-дағы бұрынғы елшісі Қ. Сұлтанов ҚХР-дағы экономикалық реформалар өзіне тән ерекшеліктермен дамуда деп атап көрсетті. Оның пікірінше, Кытайдағы реформалар барынша саяси үрдісті сақтай отырып жүргізілді және реформалар қоғамды біріктіріп, халықты аштық пен кедейліктен сақтап қалды.

\section{Әдебиеттер}

1 Назарбаев рассказал об отношениях с Китаем //https://kapital.kz/economic/20892/nazarbaev-rasskazal-ob-otnosheniyah-s-kitaem.html 
2 Касенов У.Т. Безопасность Центральной Азии: глобальные, региональные и национальные проблемы. - Алматы: Кайнар, 1998. - 280 с.

3 Лаумулин М.Т. Китайско-центральноазиатские отношения: геополитика и безопасность (взгляд с Запада) // Казахстан-Спектр. - Алматы, КИСИ, 1998. - С. 64-95. - №2(4).

4 Бжезинский. Великая шахматная доска. - М.: Международные отношения, 2000. - 254 c.

5 Фуллер Т. «Новый Шелковый путь» - ключевой элемент в стратегии Вашингтона по Афганистану, Клинтон

6 Сапанов С.Ж. Делимитация и демаркация казахстанско-китайской границы. - Алматы: Қазақ университеті, 2016. C 17.

7 Там же. - С 30.

8 Олкот М. Ислам в Узбекистане всегда был «живым организмом» // http://www.centrasia.ru/newsA.php?st=1331260260

9 Сыроежкин К.Л. Китай и Центральная Азия: политические отношения и торгово-экономическое партнерство// Казахстан - Спектр. - 1997. - № 1-2. - С.102-112.

\section{References}

1 Nazarbaev rasskazal ob otnoshenijah s Kitaem //https://kapital.kz/economic/20892/nazarbaev-rasskazal-ob-otnosheniyahs-kitaem.html

2 Kasenov U.T. Bezopasnost' Central'noj Azii: global'nye, regional'nye i nacional'nye problemy. - Almaty: Kajnar, 1998. $280 \mathrm{~s}$.

3 Laumulin M.T. Kitajsko-central'noaziatskie otnoshenija: geopolitika i bezopasnost' (vzgljad s Zapada) //Kazahstan-Spektr. - Almaty, KISI, 1998. - S. 64-95. - №2(4).

4 Bzhezinskij. Velikaja shahmatnaja doska. - M.: Mezhdunarodnye otnoshenija, 2000. - $254 \mathrm{~s}$.

5 Fuller T. «Novyj Shelkovyj put'» - kljuchevoj jelement v strategii Vashingtona po Afganistanu, Klinton

6 Sapanov S.Zh. Delimitacija i demarkacija kazahstansko- kitajskoj granicy. - Almaty: «Қаzaқ universiteti», 2016. - S 17.

7 Tam zhe. - S 30.

8 M.Olkot. Islam v Uzbekistane vsegda byl «zhivym organizmom» // http://www.centrasia.ru/newsA.php?st=1331260260

9 Syroezhkin K.L. Kitaj i Central'naja Azija: politicheskie otnoshenija i torgovo-jekonomicheskoe partnerstvo// Kazahstan Spektr. - 1997. - № 1-2. - S.102-112. 